\title{
Diversity, distribution and habitat requirements of aquatic insect communities in tropical mountain streams (South-eastern Guinea, West Africa)
}

\author{
Oi Edia Edia ${ }^{1,2 *}$, Emmanuel Castella ${ }^{2}$, Mexmin Koffi Konan ${ }^{1}$, Jean-Luc Gattolliat ${ }^{3}$ \\ and Allassane Ouattara ${ }^{1}$ \\ 1 Laboratoire d'Environnement et de Biologie Aquatique, Université Nangui Abrogoua, Abidjan, Ivory Coast \\ ${ }^{2}$ Institut F.A. Forel, Section des Sciences de la Terre et de l'Environnement \& Institut des Sciences de l'Environnement, \\ Université de Genève, Genève, Switzerland \\ 3 Musée Cantonal de Zoologie, Lausanne, Switzerland
}

Received 28 May 2015; Accepted 1 May 2016

\begin{abstract}
Considering that knowledge of the biodiversity of a region is the first step toward its conservation and given the paucity of studies on aquatic insects from the Simandou streams, the diversity of these communities was assessed. Aquatic insects were sampled with a hand-net (mesh size: $250 \mu \mathrm{m}$ ) on four occasions between March 2011 and September 2012 at 27 sites. Environmental variables were also recorded. Overall, 129 taxa belonging to 51 families and eight orders were recorded. Multivariate analyses gathered sites into three clusters in regard to aquatic insect composition. The rarefied taxonomic richness showed decreases in association with increasing levels of human impact. Cluster 1 that contained most disturbed sites displayed low taxonomic richness compared with the two others. The highest taxonomic richness was registered in cluster 2 that contained a mixture of upland and lowland sites; the latter remained minimally disturbed. These sites could be considered as reference sites in studies for assessing water quality. Generalised additive models calculated for the most frequent taxa showed that water temperature, dissolved oxygen, conductivity and $\mathrm{pH}$ were the incorporated explanatory variables. Therefore, further anthropogenic activities should preserve the surrounding forest in order to preserve the quality of Simandou streams and consequently aquatic biodiversity.
\end{abstract}

Key words: West Africa / mountain streams / generalized additive models / taxonomic diversity / aquatic insects

\section{Introduction}

Streams and rivers are among the most threatened ecosystems of the world (Dudgeon et al., 2006; Hering et al., 2006), particularly those in tropical regions (Boyero and Bailey, 2001). Estimates of the current biodiversity loss in these ecosystems are alarming (Allan and Castillo, 2007). As a result, deterioration of aquatic biodiversity has become one of the main concerns in recent conservational and ecological studies in various parts of the world (Rawi et al., 2013).

Tropical rivers support a rich but incompletely known biota (Tomanova et al., 2006). Therefore, the principal topics of biodiversity studies in this area are taxonomy, species inventory and distribution. Only once

\footnotetext{
*Corresponding author: square_edia@ymail.com
}

this basic information is established can tropical freshwater systems be viewed in a more holistic manner (Hyslop and Hunte-Brown, 2012). Significant efforts should also be made to develop realistic models of the structure and functioning of pristine or little modified tropical streams (Tomanova et al., 2006). In addition, there is growing interest in Africa for the use of aquatic invertebrates as indicators of water quality and ecosystem changes (Thorne et al., 2000; Dickens and Graham, 2002; Ndaruga et al., 2004; Kasangaki et al., 2006, 2008; Arimoro et al., 2007). Some of the compelling reasons for the apparent popularity of these communities as bioindicators are that they are ubiquitous, species-rich and long-lived. Given their ability to integrate temporal conditions, they provide evidence of environmental conditions over long periods of time (Imoobe and Ohiozebau, 2009). 
In sub-Saharan Africa, tropical forests are increasingly threatened by accelerating rates of forest conversion and degradation (Kasangaki et al., 2008). However, tropical montane cloud forests are ranked among the most important ecosystems for sustaining life in tropical regions (Bubb et al., 2004). Typical for montane areas are first- and second-order headwater streams that offer another vital service to humankind, namely the storage, regulation and purification of water (Bücker et al., 2010). Downstream human populations rely on the supply of a certain amount of quality drinking and irrigation water. All these services depend on healthy ecosystems that are currently endangered by degradation (Doumenge et al., 1995).

In this study, we focussed on mountain streams in the Simandou Range located in the south-east of the Republic of Guinea (West Africa). Long-term biomonitoring surveys of aquatic insects were carried out in several large rivers of West Africa during the Onchocerciasis (River Blindness) Control Programme (Lévêque et al., 2003) and recent studies have been carried out in Ivory Coast (Edia et al., 2010; Kouamé et al., 2011; Diomandé et al., 2014), Ghana (Benbow et al., 2014) and Nigeria (Olomukoro and Ezemonye, 2007; Arimoro et al., 2011). To our knowledge, aquatic insects in streams of Guinea in general and particularly those from the Simandou streams remain largely undocumented. Based on its montane habitats, altitudinal range and relatively intact forest, the Simandou was thought likely to contain a high biotic diversity. In addition, the Simandou Range also harbours potential mineralogical wealth and, in particular, extensive iron ore deposits. Exploratory operations are underway in the area to determine the quality, quantity and location of iron ore resources. Unfortunately, further exploitation of these resources could negatively impact streams and consequently aquatic organisms by increased deforestation, erosion, streambed modification and associated disturbances. It is therefore important to preserve these water resources and maintain their good ecological status (Gama et al., 2014).

Considering that knowledge of the biodiversity of a region is the first step toward its conservation (Heino et al., 2005) and given the paucity of studies on aquatic insects from the Simandou streams and Guinea in general, our objectives were to assess the diversity of aquatic insect communities and the habitat requirements of these communities in this area. We aimed to examine the following topics: (i) patterns of aquatic insect distribution, and (ii) environmental variables best explaining the occurrence of major aquatic insect taxa from these streams.

\section{Materials and methods}

\section{Study area and sampling sites}

The Simandou Range is located in the southeast of the Republic of Guinea, near its border with Ivory
Coast and Liberia (Fig. 1), close to the town of Beyla. This tropical area is seasonally humid and dominated by the 'West African Monsoon'. The rainy season $\left(1300-1800 \mathrm{~mm} . \mathrm{year}^{-1}\right)$ lasts from May to October and the dry season from November to April. Between 90 and $95 \%$ of the annual rainfall occurs during the wet season (Extence et al., 2013).

In West Africa, almost the whole of the GuineoCongolian Region is underlain by Precambrian rock. The landscape is formed by relatively low plateaux and plains interrupted by residual inselbergs and small higher plateaux. The Simandou Range rises above the basement plain by some $600-800 \mathrm{~m}$ with the main ridge ranging in elevation from 1250 to $1650 \mathrm{~m}$ a.s.l.

Overall, 27 sites were sampled. They were located on tributaries or in the upstream parts of the three main rivers (Milo, Loffa and Diani) belonging to different catchments. The studied streams were selected to cover a range along a disturbance gradient from intact forested sites to degraded sites. The possible degradation (adjacent land use and instream disturbance) was assessed visually by the presence of anthropogenic activities such as farming, habitation, roads, water collection, washing and/or bathing. Site characteristics are summarized in Table 1.

\section{Data collection}

Samples were collected on four occasions (i.e. two during the rainy season (September 2011 and 2012) and two during the dry season (March 2011 and 2012)) at each site. Aquatic insects were sampled with a multi-habitat approach (Hering et al., 2004). Subsamples were taken over a $30 \mathrm{~m}$ reach proportionally to macrohabitat coverage (mineral: mud, silt, sand, stones, bedrock; biotic: floating or submerged macrophytes, bank vegetation, living and fallen wood, algae/periphyton) (Minaya et al., 2013) and were specific to each available habitat at each sampling site. Subsamples were collected starting downstream with a hand-net (mesh size: $250 \mu \mathrm{m}$ ) while manually disturbing the upstream located patches for 1 min. Aquatic insects sorted in-situ within each subsample were pooled into samples and preserved in $70 \%$ ethanol. They were identified in the laboratory to the finest taxonomic resolution possible by means of the keys in Déjoux et al. (1981), Durand and Lévêque (1981), De Moor et al. (2003a, b), Day et al. (2003) and Stals and De Moor (2007).

At each site and each campaign, dissolved oxygen concentration, electrical conductivity, water temperature, $\mathrm{pH}$ and oxidation-reduction potential (ORP) were measured in-situ with a YSI Professional Plus meter (YSI Inc., USA). Water samples were collected using $500 \mathrm{~mL}$ plastic bottles, transported to the laboratory under cool conditions and were stored at $4{ }^{\circ} \mathrm{C}$ for total suspended solids (TSS) analysis. In the laboratory, TSS was determined gravimetrically from $\mathrm{GF} / \mathrm{F}$ filters after drying $\left(60^{\circ} \mathrm{C}\right)$ to constant weight. 


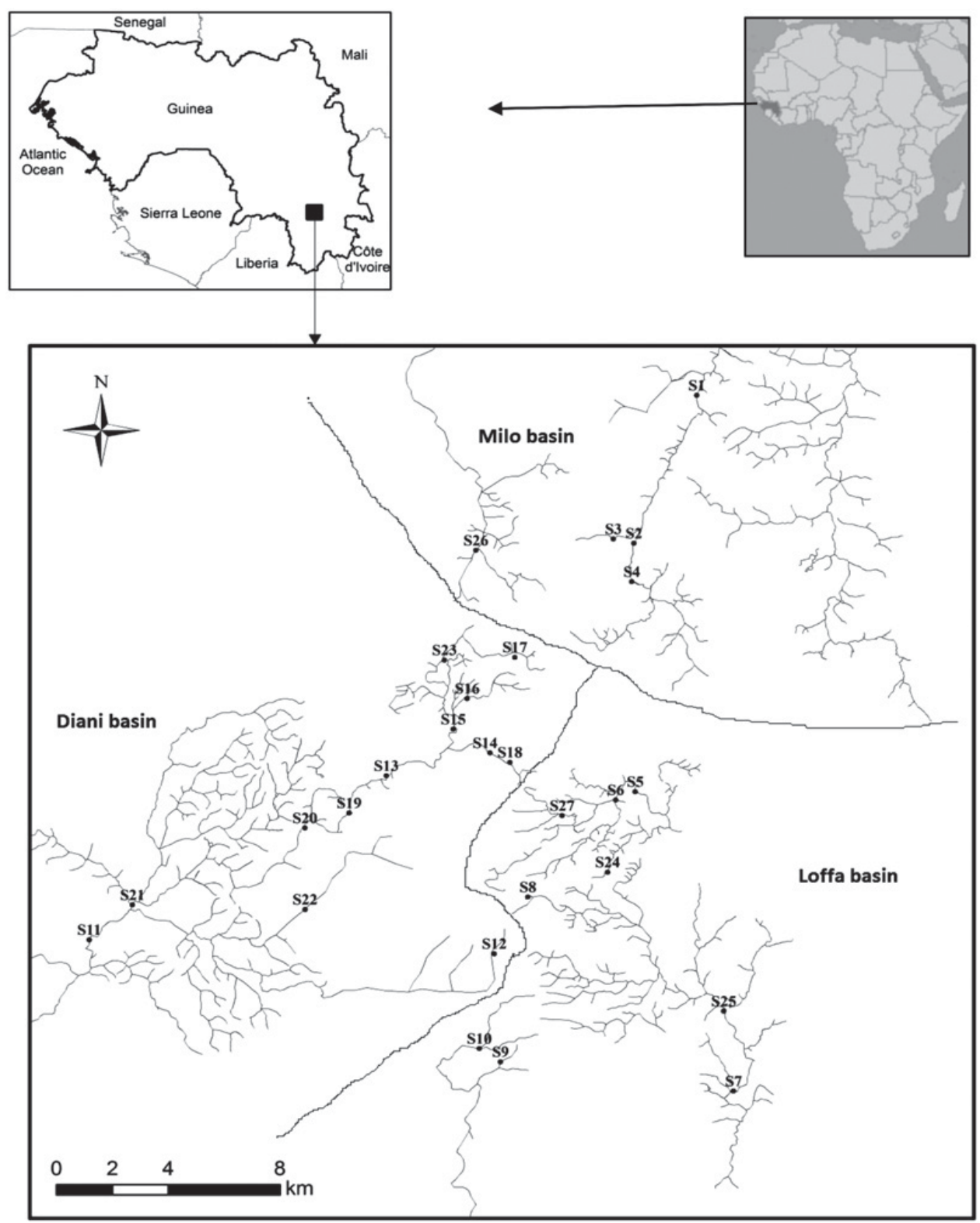

Fig. 1. Location of the study area showing the sampling sites (S1-S27).

\section{Data analysis}

Taxon richness was rarefied to avoid any bias related to differences in abundances between samples (Heck et al., 1975). The rarefaction was applied to the total taxonomic richness per site using the lowest abundance (120 individuals for this study) found in all sites as the target number of individuals (Oksanen et al., 2013). Calculations were performed using the vegan package (Oksanen et al., 2013) for the R 3.0.2 freeware (R Core Team, 2013).

Correspondence analysis (CA) was used to ordinate the samples according to taxa presence-absence, thus summarizing spatial variability of aquatic insect communities. Between-class CA and permutation tests were carried out to assess the relative extent and significance of spatial variability (Dolédec and Chessel, 1989; Baty et al., 2006). The classes of the between-class CA were catchments and sampling sites. The taxonomic similarity between sites was then investigated using Ward's clustering method applied to the between-site CA scores. Between-cluster CA and permutation tests were carried out to assess the relative extent and significance of site clustering. The classes of the between-class CA were clusters. Rare taxa (taxa occurring in less than 5\% of the samples) were removed. The analyses were computed with the ade4 package (Chessel et al., 2004) for the R 3.0.2 freeware.

Indicator values (IndVal) were calculated according to Dufrêne and Legendre (1997) to identify the most discriminant taxa for each site cluster. The statistical significance of the indicator values was evaluated using a 
Table 1. Characteristics of the sampling sites.

\begin{tabular}{|c|c|c|c|c|c|c|c|c|c|}
\hline \multirow[b]{2}{*}{ Stations } & \multirow[b]{2}{*}{ Streams } & \multicolumn{2}{|c|}{ Coordinates (UTM) } & \multirow{2}{*}{$\begin{array}{l}\text { Altitude } \\
(\mathrm{m})\end{array}$} & \multirow[b]{2}{*}{ Category } & \multirow{2}{*}{$\begin{array}{c}\text { Disturbance } \\
\text { degree }\end{array}$} & \multirow{2}{*}{$\begin{array}{l}\text { Adjacent } \\
\text { land use }\end{array}$} & \multirow{2}{*}{$\begin{array}{l}\text { Instream } \\
\text { disturbance }\end{array}$} & \multirow{2}{*}{$\begin{array}{c}\text { Population } \\
\text { density* }\end{array}$} \\
\hline & & $\mathrm{S}$ & $\bar{E}$ & & & & & & \\
\hline$\overline{\mathrm{S} 1}$ & Miya & 517119 & 963799 & 650 & Lowland & High & $\begin{array}{c}\text { Bridge, road } \\
\text { and village }\end{array}$ & $\begin{array}{l}\text { Washing } \\
\text { and bathing }\end{array}$ & High \\
\hline $\mathrm{S} 2$ & Miya & 514868 & 958207 & 678 & Upland & Moderate & $\begin{array}{c}\text { permanent } \\
\text { presence } \\
\text { of cattle }\end{array}$ & None & None \\
\hline S3 & Boboiba & 514130 & 958365 & 689 & Upland & Low & Riparian forest & None & None \\
\hline S4 & Miya & 514787 & 956748 & 694 & Upland & Low & Old rice field & None & None \\
\hline S5 & Loffa & 514915 & 948832 & 762 & Upland & Low & Bridge, road & Bridge, road & None \\
\hline S6 & Loffa tributary1 & 514216 & 948517 & 780 & Upland & Low & Old rice field & None & None \\
\hline S7 & Loffa & 518433 & 937509 & 600 & Lowland & Low & Old rice field & Bathing & Low \\
\hline S8 & Loffa tributary2 & 511074 & 944847 & 1177 & Upland & None & Riparian forest & None & None \\
\hline S9 & Foko & 510091 & 938614 & 852 & Upland & None & Riparian forest & None & None \\
\hline $\mathrm{S} 10$ & Foko & 509334 & 939116 & 797 & Upland & None & Riparian forest & None & None \\
\hline S11 & Soumourou & 495367 & 943228 & 524 & Lowland & Moderate & Farming & $\begin{array}{l}\text { Washing } \\
\text { and bathing }\end{array}$ & Low \\
\hline $\mathrm{S} 12$ & Whisky 2 & 509870 & 942700 & 1213 & Upland & None & Riparian forest & None & None \\
\hline S13 & Woron & 506004 & 949430 & 572 & Lowland & Low & Old rice field & water collection & Low \\
\hline S14 & Worongbê & 509714 & 950299 & 750 & Upland & None & Riparian forest & None & None \\
\hline S15 & Woronfi & 508402 & 951193 & 578 & Lowland & Low & $\begin{array}{l}\text { Riparian forest, } \\
\text { old rice field }\end{array}$ & None & None \\
\hline S16 & Woronfi & 508896 & 952353 & 685 & Upland & None & Riparian forest & None & None \\
\hline S17 & Woron tributary & 510601 & 953914 & 906 & Upland & None & Riparian forest & None & None \\
\hline S18 & Worongbê & 510430 & 949942 & 801 & Upland & None & Riparian forest & None & None \\
\hline S19 & Woron & 504669 & 948025 & 564 & Lowland & None & Riparian forest & None & None \\
\hline S20 & Woron & 503090 & 947458 & 544 & Lowland & Moderate & Farming, village & $\begin{array}{l}\text { Washing } \\
\text { and bathing }\end{array}$ & Low \\
\hline $\mathrm{S} 21$ & Soumourou & 496910 & 944550 & 520 & Lowland & Moderate & $\begin{array}{l}\text { Bridge, road, } \\
\text { farming }\end{array}$ & water collection & Low \\
\hline $\mathrm{S} 22$ & Kpolowai & 503095 & 944377 & 534 & Lowland & High & Village, farming & $\begin{array}{l}\text { Washing } \\
\text { and bathing }\end{array}$ & High \\
\hline $\mathrm{S} 23$ & Woronfi & 508085 & 953807 & 702 & Upland & None & Riparian forest & None & None \\
\hline S24 & Loffa tributary3 & 513923 & 945786 & 871 & Upland & None & Riparian forest & None & None \\
\hline $\mathrm{S} 25$ & Loffa & 518079 & 940531 & 620 & Lowland & None & Riparian forest & None & None \\
\hline S26 & Mala & 509209 & 957937 & 699 & Upland & Low & Old rice field & None & None \\
\hline $\mathrm{S} 27$ & Loffa tributary4 & 512292 & 947925 & 804 & Upland & None & Riparian forest & None & None \\
\hline
\end{tabular}

* Low: discontinuous habitation along the banks; High: continuous habitation.

randomization procedure with 999 permutations (Dufrêne and Legendre, 1997). This analysis was performed using the indicspecies package (De Caceres and Jansen, 2013) for the R 3.0.2 freeware.

A preliminary Shapiro test outlined the non-normality of data in some of the clusters. Variations in environmental variables and in rarefied richness between clusters defined by the hierarchical analysis were determined using a Kruskal-Wallis test. When the KruskalWallis test was significant, a Wilcoxon test was used for pairwise comparison. The significance threshold was $P=0.05$.

Relationships of the most frequent taxa (taxa occurring in at least $50 \%$ of the 108 samples ( 27 sites $\times 4$ periods) with environmental variables were analysed using GAMs (Hastie and Tibshirani, 1990), with the aim of identifying the main variables influencing their occurrence. All five environmental variables with a pairwise correlation of $r<0.8$ (Pearson's correlation, $P<0.05$ ) (Table 2) were included in the GAMs. In the models, the TSS values were $\log 10(x+1)$ transformed. Binomial family distributions and log-link functions were used to ensure that all fitted values were positive (Fuentes-Rodriguez et al., 2013). An $F$-test was used to obtain the significance of the deviance explained by each dropped variable. The contribution of each explanatory variable was expressed as the deviance reduction associated with dropping the variable from the final model (Castella et al., 2001). These models were implemented using the $m g c v$ package (Wood, 2014) for the R 3.0.2 freeware.

\section{Results}

\section{Taxonomic richness and composition}

A total of 129 aquatic insect taxa belonging to 51 families and eight orders were recorded (Appendix). The number of taxa identified at each site ranged from 27 (S11) to 71 (S2). The richest orders of insects were Coleoptera 
Table 2. Pearson's correlation coefficient (r) between explanatory environmental variables used in GAMs.

\begin{tabular}{llcrrr}
\hline Variable & Code & Temp & Cond & DO & pH \\
\hline Water temperature & Temp & & & \\
Conductivity & Cond & $0.30^{* * *}$ & & & \\
Dissolved oxygen & DO & $-0.36^{* * *}$ & $-0.22^{* * *}$ & & \\
pH & pH & $0.19^{*}$ & $0.41^{* * *}$ & -0.13 & 0.16 \\
Oxidation-reduction potential & ORP & $-0.34^{* * *}$ & 0.09 & 0.07 & -0.01 \\
Total sediment suspended & TSS & -0.03 & 0.09 & 0.02 & 0.03 \\
\hline
\end{tabular}

*** $r$ significantly different from 0 at $P<0.001$.

* $r$ significantly different from 0 at $P<0.05$.

No asterisk: $r$ not significantly different from $0(P>0.05)$.
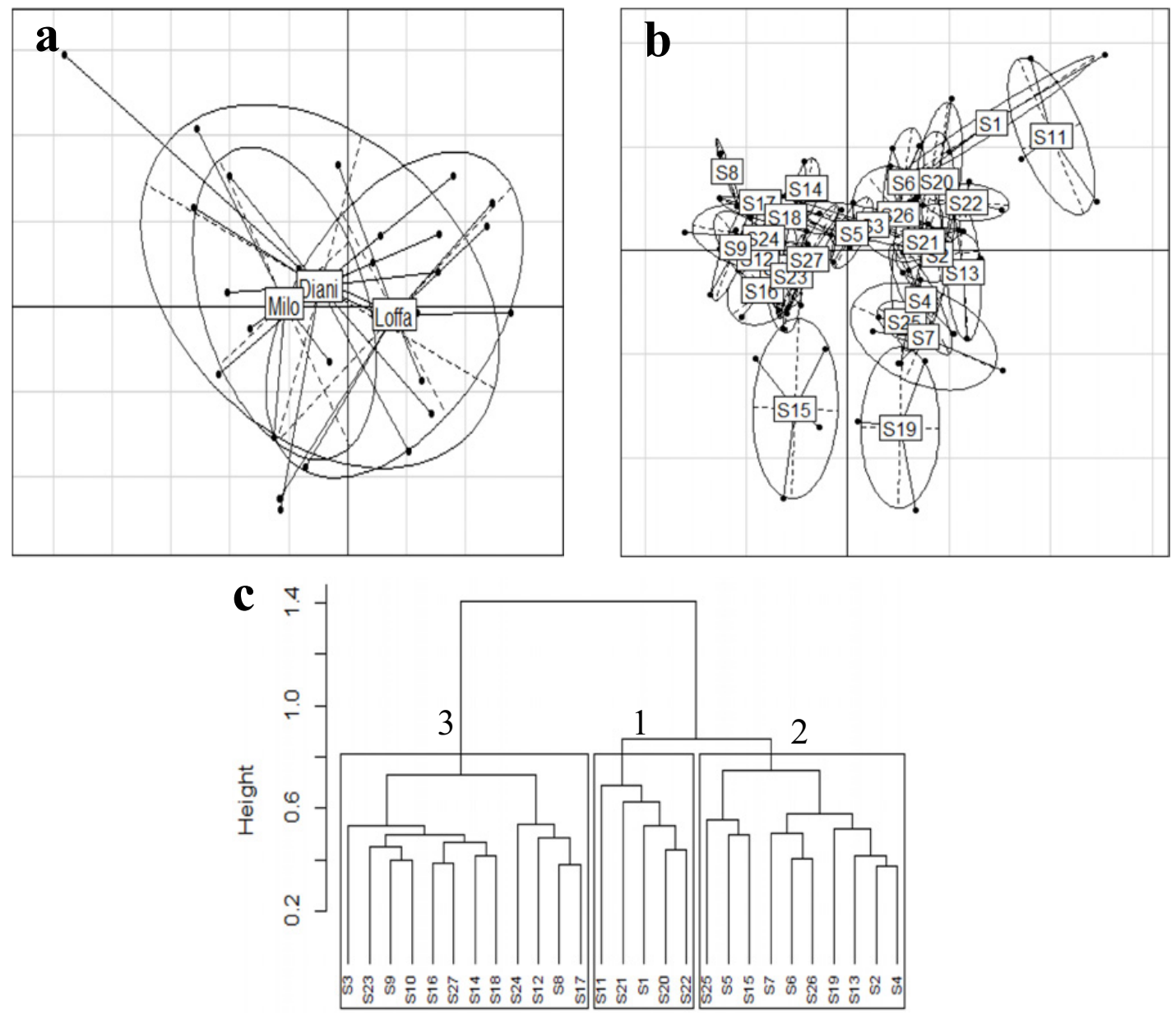

Fig. 2. Correspondence analysis of the taxonomic data (CA) showing (a) between-catchment (F1: 18.5.7\% and F2: 11.5\% of explained variation) and (b) between-site (F1: 16.8\% and F2: 9.5\% of explained variations) variations, and (c) hierarchical cluster summarising between-site similarities in aquatic insect assemblages. S1-S27: sampling sites, DS: dry season, WS: wet season, 11 and 12: years 2011 and 2012, 1-3: cluster numbers.

(29 taxa) and Ephemeroptera (26 taxa) followed by Odonata (25 taxa). Plecoptera was represented by one taxon (Neoperla spio) and was the most abundant order.

Overall, the macroinvertebrate fauna was predominantly composed of ten taxa that were present in more than $50 \%$ of the samples: five Ephemeroptera (Adenophlebiodes sp., Dicercomyzon sp., Caenis sp., Labiobaetis sp., Afronurus sp.), one Plecoptera (Neoperla spio), two Trichoptera (Leptocerus sp., Hydropsyche sp.) and two Diptera (Chironominae, Limnophila sp.).
The between-catchment CA (Fig. 2a) explained only $3.6 \%$ of the total assemblage variation (permutation test, $P<0.001$ ). The between-site CA (Fig. 2b) explained $32.6 \%$ of the total assemblage variation (permutation test, $P<0.001$ ). Hierarchical clustering using the distance calculated by the between-site CA grouped sites into three clusters (Fig. 2c). The sites were clustered according to their taxa composition, and the catchments had no effect. The permutation test on between-cluster CA was significant $(P<0.001)$. Cluster 1 consisted of five sites, 


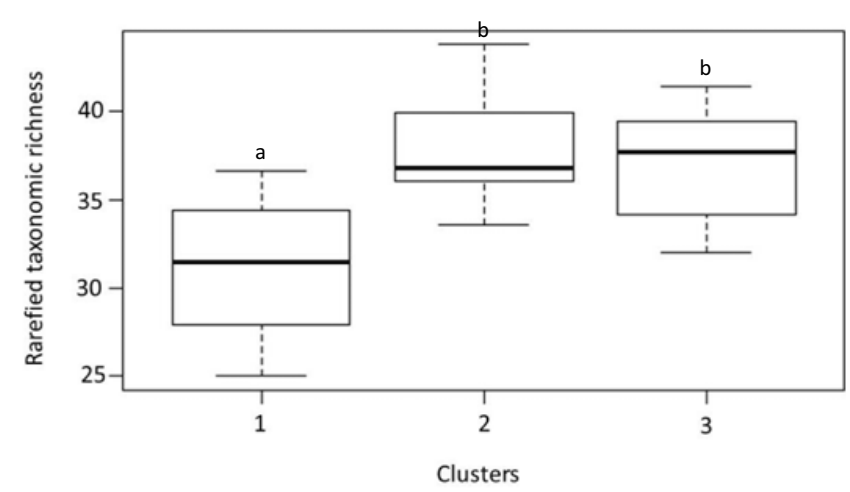

Fig. 3. Box-plots showing differences in rarefied taxonomic richness (calculated for 120 individuals) between site clusters (1-3). Different letters on box-plots denote significant differences between them $(P<0.05$; Wilcoxon test $)$.

which are the most disturbed by anthropogenic activities, such as agricultural and domestic activities, as they are located close to populated areas (see Table 1). Clusters 2 and 3 were composed respectively of 10 and 12 sites, which are relatively free from disturbance as they are located in unpopulated areas. The Kruskal-Wallis test showed significant differences in rarefied richness between clusters $\left(\chi^{2}=6.07, P<0.05\right.$, Fig. 3). Cluster 1 displayed the lowest rarefied taxonomic richness and was significantly different from clusters 2 and 3 (Wilcoxon test, $W=5, \quad P<0.05)$. There was no significant difference (Wilcoxon test, $W=70, P>0.05$ ) between clusters 2 and 3 . However, cluster 2 contained the sites with the highest rarefied richness.

Six taxa had significant indicator values (permutation test, $P<0.05$ ) (Table 3 ): cluster 1 was mainly characterized by Lestinogomphus sp., cluster 2 by Leptelmis sp. and Tricorythus sp., and cluster 3 by Ephemera sp., Afrobrianax ferdyi and Chimara sp.

\section{Environmental characteristics of the site clusters}

The variations of environmental variables among clusters are shown in Figure 4. Cluster 3 gathered sites with a relatively high altitude (upland) in comparison with those of cluster 1 (Wilcoxon test, $W=2, P<0.05$ ) and cluster 2 (Wilcoxon test, $W=12, P<0.05$ ). Cluster 2 contained a mixture of lowland and upland sites (see Table 1).
The highest values of dissolved oxygen were registered in cluster 3 compared with those of cluster 1 (Wilcoxon test, $W=7, P<0.05$ ) and cluster 2 (Wilcoxon test, $W=31$, $P<0.05)$. Conversely, values for water temperature, conductivity and $\mathrm{pH}$ in cluster 1 (respectively Wilcoxon test, $W=42,44$ and 47.5 ) and cluster 2 (respectively Wilcoxon test, $W=112,127$ and 116$)$ were significantly $(P<0.05)$ higher than those of cluster 3 . There were no significant variations of TSS and ORP between clusters (respectively Kruskal-Wallis $\chi^{2}=2.68$ and 2.48, $P>0.05$ ).

\section{Taxa relationships with environmental variables}

GAMs were significant for five out of the 10 most frequent taxa (Table 4). TSS and ORP never contributed significantly. Water temperature was incorporated in three models (Adenophlebiodes sp., Neoperla spio and Limnophila sp.). Dissolved oxygen was significant in two models (Neoperla spio and Dicercomyzon sp.). Conductivity and $\mathrm{pH}$ were selected as significant predictors once for Neoperla spio and Chironomidae, respectively.

The response curves for the significant variables and their confidence bands (twice the standard error) are presented in Figure 5. GAMs for Adenophlebiodes sp., Neoperla spio and Limnophila sp. showed similar trends, incorporating a quasi-linear negative influence of water temperature on the occurrence of the taxa. The contribution of conductivity and $\mathrm{pH}$ were also quasi-linear and negative for Neoperla spio and Chironominae, respectively. The models for Neoperla spio incorporated a quasilinear and positive response to dissolved oxygen. The influence of this variable for Dicercomyzon sp. seemed bellshaped.

\section{Discussion}

To our knowledge, this study represents the first published data on aquatic insects in Simandou streams and one of the very few for the whole Republic of Guinea. The taxonomic richness (129) registered in this study is high when compared with earlier studies from West Africa, particularly in Ivory Coast. For example, Diomandé et al. (2009) used an Ekman sampler to collect 50 taxa from one site in the Agnéby River. This difference in taxonomic richness probably reflects differences in sampling methods and habitat coverage as demonstrated

Table 3. Significant indicator taxa (IndVal, $P<0.05$ ) for each site cluster.

\begin{tabular}{lccc}
\hline Indicator taxa & Cluster & IndVal & \\
\hline Lestinogomphus sp. & 1 & 0.816 & Probability \\
Leptelmis sp. & 2 & 0.827 & 0.005 \\
Tricorythus sp. & 2 & 0.791 & 0.001 \\
Ephemera sp. & 3 & 0.866 & 0.001 \\
Afrobrianax ferdyi & 3 & 0.863 & 0.001 \\
Chimara sp. & 3 & 0.645 & 0.001 \\
\hline
\end{tabular}



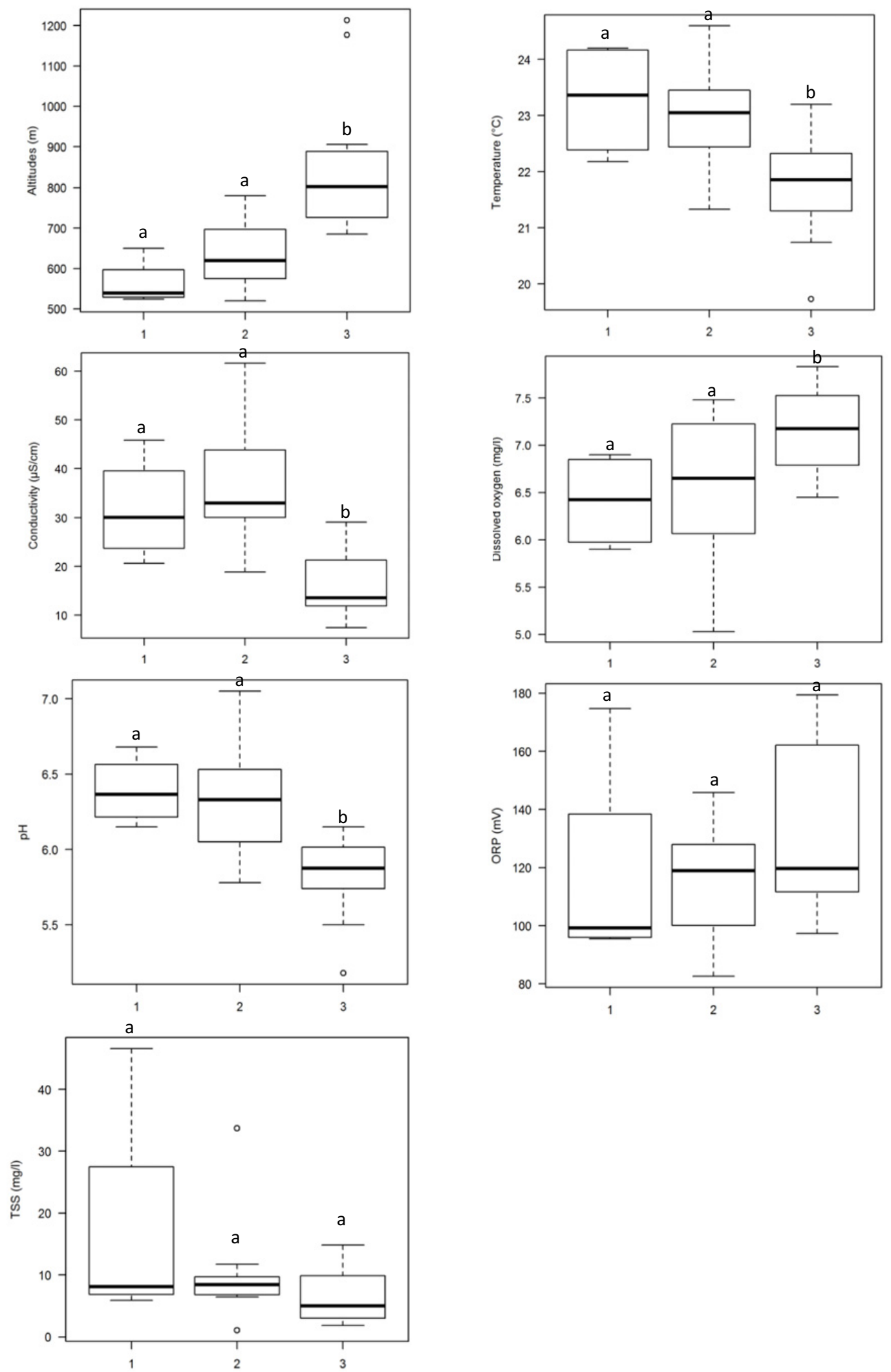

Fig. 4. Box-plots showing differences in environmental variables between site clusters (1-3). Different letters on box-plots denote significant differences between them $(P<0.05$; Wilcoxon test $)$. 
Table 4. Results of generalized additive models testing the contribution of selected environmental variables to explain the occurrence of the most frequent taxa. For each taxon, environmental variables were kept in models when $P<0.05$ (in bold).

\begin{tabular}{|c|c|c|c|c|c|c|c|c|c|c|c|c|c|c|c|c|}
\hline \multirow[b]{3}{*}{ Taxon } & \multirow[b]{3}{*}{$n$} & \multirow[b]{3}{*}{$P$} & \multirow[b]{3}{*}{$r^{2}$} & \multirow{3}{*}{$\begin{array}{c}\text { Deviance } \\
\text { explained }(\%)\end{array}$} & \multicolumn{12}{|c|}{ Explanatory variables } \\
\hline & & & & & \multicolumn{2}{|c|}{ Temp } & \multicolumn{2}{|c|}{ Cond } & \multicolumn{2}{|l|}{ DO } & \multicolumn{2}{|l|}{$\mathrm{pH}$} & \multicolumn{2}{|c|}{ ORP } & \multicolumn{2}{|c|}{ TSS } \\
\hline & & & & & $F$-value & $P$ & $F$-value & $P$ & $F$-value & $P$ & $F$-value & $P$ & $F$-value & $P$ & $F$-value & $P$ \\
\hline$\overline{\text { Adenophlebiodes sp. }}$ & 76 & $<0.05$ & 0.29 & 38.7 & 7.19 & 0.01 & 2.45 & 0.12 & 2.23 & 0.14 & 1.10 & 0.3 & 0.01 & 0.96 & 0.86 & 0.36 \\
\hline Neoperla spio & 73 & $<0.001$ & 0.26 & 27.5 & 16.84 & 0.01 & 6.29 & 0.01 & 5.62 & 0.02 & 3.59 & 0.06 & 1.23 & 0.27 & 0.62 & 0.44 \\
\hline Dicercomyzon sp. & 70 & $<0.05$ & 0.17 & 24.1 & 0.10 & 0.98 & 0.32 & 0.57 & 5.59 & 0.02 & 1.62 & 0.21 & 1.19 & 0.28 & 0.02 & 0.90 \\
\hline Limnophila sp. & 62 & $<0.05$ & 0.13 & 38.8 & 5.27 & 0.02 & 0.48 & 0.49 & 0.03 & 0.87 & 1.26 & 0.26 & 0.23 & 0.63 & 0.51 & 0.48 \\
\hline
\end{tabular}

See Table 2 for variable codes.

by Maue and Springer (2008). Moreover, this relative high diversity could be due to the fact that the studied areas covered mostly the headwater and mid-streams. Several studies claim high levels of taxonomic richness in these areas (Dieterich and Anderson, 2000; Baptista et al., 2001; Cole et al., 2003; Herlihy et al., 2005). On the other hand, the number of taxa found in the Simandou streams is more similar to that reported, using the same sampling methods, for south-eastern Ivory Coast (124 taxa in eight sites, Edia et al., 2010) and southern Ivory Coast (132 taxa in seven sites, Camara et al., 2012). In the Macaé river basin (Rio de Janeiro, Brazil), Baptista et al. (2001) registered 117 taxa. In other tropical regions (Vietnam), the aquatic insect richness (268) obtained by Hoang and Bae (2006) using qualitative and quantitative sampling methods was twice as high as that of our study.

The observed taxonomic richness decreased with increasing levels of human impact in the Simandou streams. Sites (gathered in cluster 1) that were more disturbed by anthropogenic activities (agricultural and domestic activities), and located closer to populated areas, contained lower taxonomic richness. On the contrary, high taxonomic richness was registered in the sites with low human impacts (gathered in clusters 2 and 3). The same pattern was found in temperate (Evans-White et al., 2009), tropical (De Jesus-Crespo and Ramirez, 2011), and mountain stream systems (Miserendino et al., 2008). Site cluster 2 that displayed the highest taxonomic richness contained a mixture of upland and lowland sites, the latter remaining minimally disturbed (Table 1). Thus, in further studies for assessing water quality, such sites could be considered as references. These sites that were suitable for monitoring were characterized by colder water, high oxygen concentrations, low conductivity and low $\mathrm{pH}$ and therefore susceptible to rapid modification in the case of mining activities or increased human pressures. These variables were influential and significantly associated with variations in the occurrence of the most frequent aquatic insects in the Simandou streams. The taxa (e.g., Leptelmis sp., Tricorythus sp., Ephemera sp., Afrobrianax ferdyi and Chimara sp.) associated with these reference sites and the most frequent taxa (e.g., Adenophlebiodes sp., Dicercomyzon sp., Neoperla spio and Limnophila sp.) could be used as sentinels for alteration of the studied streams. The characteristic taxa associated with relatively unimpacted sites gathered in clusters 2 and 3 were polluo-sensitive (Dickens and Graham, 2002). Except for Ephemera sp. and Tricorythus sp., the remaining taxa (elmid beetle Leptelmis sp., psephenid beetle Afrobrianax ferdyi and philopotamid Chimara sp.) characteristically occur in the upper reaches of streams in areas of cobbles and boulders (Ward, 1992). The burrower Ephemera sp. could also occur in headwater streams (Mellanby, 1963); it lives in tunnels constructed at the water edge. The stout crawler Tricorythus sp. inhabits fast flowing streams on rocks or any solid submerged substrate (Gerber and Gabriel, 2002). Belmar et al. (2013) also mentioned the preferential occurrence of Philopotamidae and rheophilic Ephemeroptera (such as Tricorythus sp.) in headwater streams in Spain.

Our study showed that the Gomphidae Lestinogomphus sp. was closely associated with the most disturbed lowland sites (cluster 1). While it is difficult to explain specifically the fidelity of this taxon in respect to human disturbance, it is known that the family Gomphidae is moderately tolerant to pollution (Dickens and Graham, 2002). Moreover, this gomphid larva is mostly encountered in downstream sites where the substrate is dominated by sand (Allan and Castillo, 2007).

Environmental parameters such as water temperature, dissolved oxygen, conductivity and $\mathrm{pH}$ were influential and significantly associated with variations in the occurrence of the most frequent aquatic insects in the Simandou streams. These variables were also dependent upon the altitudinal gradient. The upland forested sites were characterized by low conductivity, low temperature, acidic water and high dissolved oxygen concentration compared with lowland open sites. Moreover, aquatic insect richness was high in upland areas and also decreased with anthropogenic disturbances. As mentioned, the Simandou Range also harbours potential mineralogical wealth and, in particular, extensive iron ore deposits. Exploratory operations are underway in the area to determine the quality, quantity and location of iron ore resources. The exploitation of these resources should incorporate the preservation of the surrounding forest in upstream areas, in order to maintain and preserve aquatic biodiversity and consequently the quality of Simandou streams. Streams with minimally disturbed riparian forest contribute branches and large wood to channels, thereby increasing habitat complexity and habitats that favour increased abundance and diversity of macroinvertebrates 

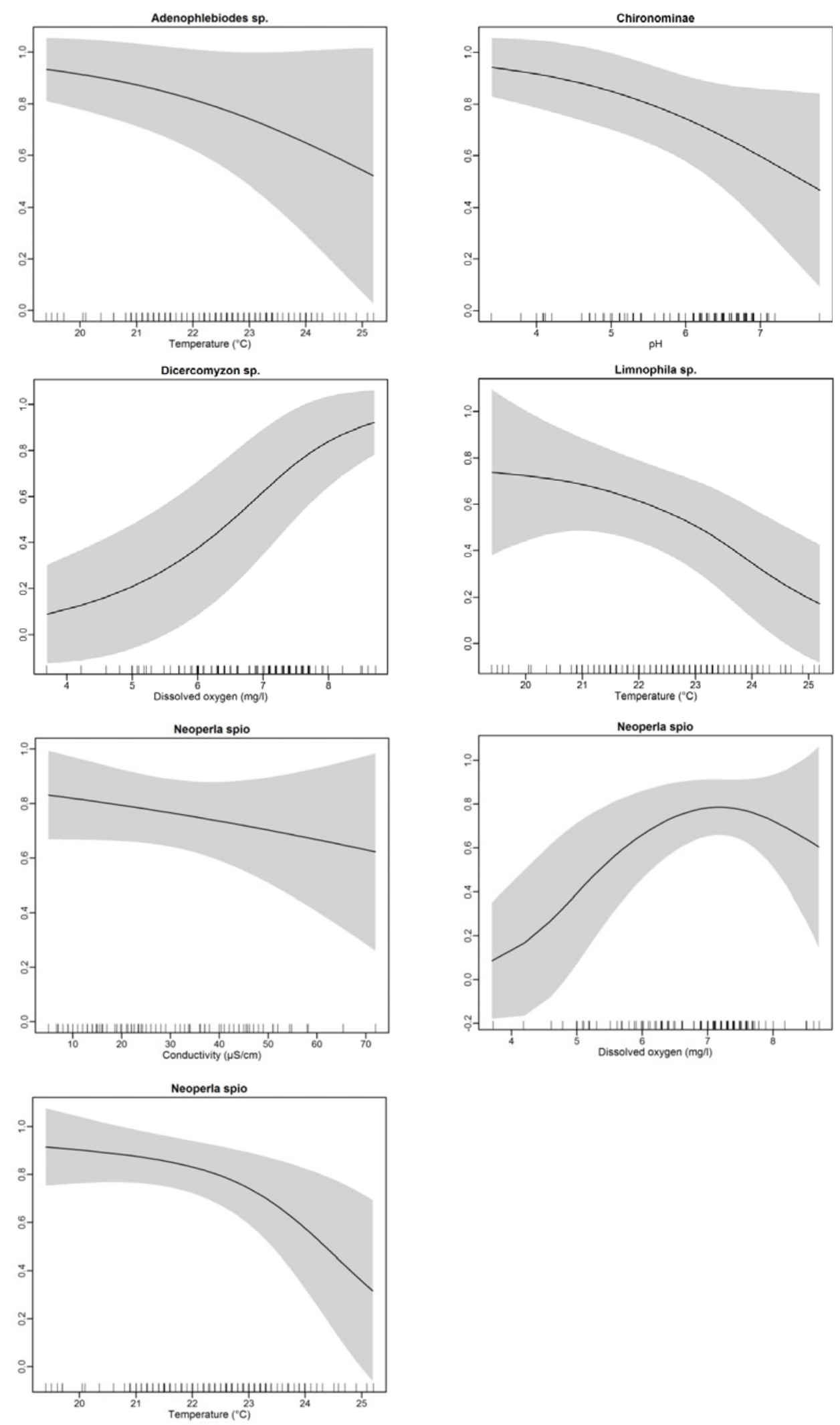

Fig. 5. Generalized additive model (GAM) response curves for the most frequent taxa. Tick marks on the $x$-axis are observed data points. The $y$-axis represents the occurrence probability of taxa. Gray bands represent $95 \%$ confidence intervals. 
(Kaufmann and Faustini, 2012; Ferreira et al., 2014). Moreover, as shown by Rawi et al. (2013) for tropical forest streams in the south-western parts of the Malaysian peninsula, all activities involving deforestation have a negative effect on aquatic biodiversity. Similar observations were made by Braun et al. (2014) in montane streams in southern Brazil and Suriyawong et al. (2015) in Huay Kaew stream at Doi Suthep-Pui National Park (Chiang Mai, Thailand).

Furthermore, intensive ecological research to investigate the drivers regulating the community structure of aquatic insects in Simandou streams is recommended. These investigations should also explore the trait-based approach, which is a powerful tool for studying mechanisms structuring communities including benthic invertebrates.

Acknowledgements. Data collection was funded by the partnership between RIO TINTO/SIMFER (Guinea) and the SYLVATROP Association (France). This paper is the outcome of an Excellence Scholarship granted to the first author by the Swiss Government. Thanks are due to all the anonymous reviewers and to the handling editor for their constructive comments and suggestions which improved the paper significantly.

\section{References}

Allan J.D. and Castillo M.M., 2007. Stream Ecology: Structure and Function of Running Waters, 2nd edn, Springer, Dordrecht, $406 \mathrm{p}$.

Arimoro F.O., Ikomi R.B. and Iwegbue C.M.A., 2007. Water quality changes in relation to Diptera community patterns and diversity measured at an organic effluent impacted stream in the Niger Delta, Nigeria. Ecol. Indic., 7, 541-552.

Arimoro F.O., Ikomi R.B., Ajuzieogu I.O. and Nwadukwe F.O., 2011. Temporal and spatial variability in macroinvertebrate community structure in relation to environmental variables in Ajijiguan Creek, Niger Delta, Nigeria. Afr. J. Aquat. Sci., $36,57-66$.

Baptista D.F., Buss D.F., Dorvillé L.F.M. and Nessimian J.L., 2001. Diversity and habitat preference of aquatic insects along the longitudinal gradient of the Macaé river basin, Rio de Janeiro, Brazil. Rev. Brasil. Biol., 61(2), 249-258.

Baty F., Facompré M., Wiegand J., Schwager J. and Brutsche M.H., 2006. Analysis with respect to instrumental variables for the exploration of microarray data structures. BMC Bioinformatics, 7, 422-429.

Belmar O., Velasco J., Gutiérrez-Cánovas C., Mellado-Díaz A., Millán A. and Wood P.J., 2013. The influence of natural flow regimes on macroinvertebrate assemblages in a semiarid Mediterranean basin. Ecohydrology, 6, 363-379.

Benbow M.E., Kimbirauskas R., McIntosh M.D., Williamson H., Quaye C., Boakye D., Small P.L.C. and Merritt R.W., 2014. Aquatic Macroinvertebrate Assemblages of Ghana, West Africa: understanding the Ecology of a Neglected Tropical Disease. EcoHealth, 11, $168-183$.

Boyero L. and Bailey R.C., 2001. Organization of macroinvertebrate communities at a hierarchy of spatial scales in a tropical stream. Hydrobiologia, 464, 219-225.
Braun B.M., Pires M.M., Kotzian C.B. and Spies M.R., 2014. Diversity and ecological aspects of aquatic insect communities from montane streams in southern Brazil. Acta Limnol. Bras., 26, 186-198.

Bubb P., May I., Miles L. and Sayer J., 2004. Cloud Forest Agenda, UNEP-WCMC, Cambridge, UK, 36 p.

Bücker A., Sondermann M., Frede H.-G. and Breuer L., 2010. The influence of land-use on macroinvertebrate communities in montane tropical streams - a case study from Ecuador. Fund. Appl. Limnol., 177, 267-282.

Camara I.A., Diomandé D., Bony Y.K., Ouattara A., Franquet E. and Gourène G., 2012. Diversity assessment of benthic macroinvertebrate communities in Banco National Park (Banco Stream, Côte d'Ivoire). Afr. J. Ecol., 50, 205-217.

Castella E., Adalsteinsson H., Brittain J.E., Gislason G.M., Lehmann A., Lencioni V., Lods-Crozet B., Maiolini B., Milner A.M., Olafsson J.S., Saltveit S.J. and Snook D.L., 2001. Macrobenthic invertebrate richness and composition along a latitudinal gradient of European glacier-fed streams. Freshw. Biol., 46, 1811-1831.

Chessel D., Dufour A.B. and Thioulouse J., 2004. The ade 4 package - I: one-table methods. $R$ news, 4, 5-10.

Cole M.B., Russell K.R. and Mabee T.J., 2003. Relation of headwater macroinvertebrate communities to in-stream and adjacent stand characteristics in managed second-growth forests of the Oregon Coast Range mountains. Can. J. Fish. Aquat. Sci., 33, 1433-1443.

Day J.A., Harrison A.D. and De Moor I.J., 2003. Freshwater Invertebrates of Southern Africa, Volume 9: Diptera, WRC Report, South Africa, Pretoria, 200 p.

De Caceres M. and Jansen F., 2013. Indicspecies: Studying the statistical relationship between species and groups of sites. $\mathrm{R}$ package version 1.7.1.

De Jesus-Crespo R. and Ramirez A., 2011. Effects of urbanization on stream physico-chemistry and macroinvertebrate assemblages in a tropical urban watershed in Puerto Rico. J. N. Am. Benthol. Soc., 30, 739-750.

De Moor I.J., Day J.A. and De Moor F.C., 2003a. Freshwater Invertebrates of Southern Africa, Volume 7: Insecta I: Ephemeroptera, Odonata \& Plecoptera, WRC Report, South Africa, Pretoria, $288 \mathrm{p}$.

De Moor I.J., Day J.A. and De Moor F.C., 2003b. Freshwater Invertebrates of Southern Africa, Volume 8: Insecta II: Hemiptera, Megaloptera, Neuroptera, Trichoptera \& Lepidoptera, WRC Report, South Africa, Pretoria, 209 p.

Déjoux C., Elouard J.M., Forge P. and Maslin J.L., 1981. Catalogue Iconographique des Insectes Aquatiques de Côte d'Ivoire, Report ORSTOM, Bouaké, Côte d'Ivoire, $172 \mathrm{p}$.

Dickens C.W.S. and Graham P.M., 2002. The South African Scoring System (SASS) Version 5, rapid bioassessment method for rivers. Afr. J. Aquat. Sci., 27, 1-10.

Dieterich M. and Anderson N.H., 2000. The invertebrate fauna of summer-dry streams in western Oregon. Arch. Hydrobiol., 147, 273-295.

Diomandé D., Bony K.Y., Edia O.E., Konan F.K. and Gourène G., 2009. Diversité des macroinvertébrés benthiques de la riviére Agnéby (Côte d'Ivoire; Afrique de l'Ouest). Eur. J. Sci. Res., 35, 368-377.

Diomandé D., Camara I.A., Edia O.E. and Gourène G., 2014. Diversity and seasonal pattern of Chironomidae (Insecta; 
Diptera) in seven lotic systems of Southeast Côte d'Ivoire (West Africa). J. Bio. Env. Sci., 4, 263-274.

Dolédec S. and Chessel D., 1989. Rythmes saisonniers et composantes stationnelles en milieu aquatique II. Prise en compte et élimination d'effets dans un tableau faunistique. Acta Oecol. Oecol. Gen., 10, 207-232.

Doumenge C., Gilmour D.A., Ruiz Perez M. and Blockhus J., 1995. Tropical montane cloud forests: conservation status and management issues. In: Hamilton L.S., Juvik J.O. and Scatena F.N. (eds.), Tropical Montane Cloud Forests, Ecological Studies 110, Springer Verlag, New York, 24-37.

Dudgeon D., Arthington A.H., Gessner M.O., Kawabata Z.-I., Knowler D.J., Lévêque C., Maiman R.J., Prieur-Richard A.-H., Soto D., Stiassny M.L.J. and Sullivan C.A., 2006. Freshwater biodiversity: importance, threats, status and conservation challenges. Biol. Rev., 81, 163-182.

Dufrêne M. and Legendre P., 1997. Species assemblages and indicator species: the need for a flexible asymmetrical approach. Ecol. Monogr., 67, 345-366.

Durand J.-R. and Lévêque C., 1981. Flore et Faune de l'Afrique Sahelo-soudanienne, ORSTOM Editions, Tome II, Paris, 391-873.

Edia O.E., Gevrey M., Ouattara A., Brosse S., Gourène G. and Lek S., 2010. Patterning and predicting aquatic insect richness in four West-African coastal rivers using artificial neural networks. Knowl. Manag. Aquat. Ecosyst., 398, 06.

Evans-White M.A., Dodds W.K., Huggins D.G. and Baker D.S., 2009. Thresholds in macroinvertebrate biodiversity and stoichiometry across water-quality gradients in Central Plains (USA) streams. J. N. Am. Benthol. Soc., 28, 855-868.

Extence C.A., Chadd R.P., England J., Dunbar M.J., Wood P.J. and Taylor E.D., 2013. The assessment of fine sediment accumulation in rivers using macro-invertebrate community response. River Res. App., 29, 17-55.

Ferreira W.R., Ligeiro R., Macedo D.R., Hughes R.M., Kaufmann P.R., Oliveira L.G. and Callisto M., 2014. Importance of environmental factors for the richness and distribution of benthic macroinvertebrates in tropical headwater streams. Freshw. Sci., 33, 860-871.

Fuentes-Rodriguez F., Juan M., Gallego I., Lusi M., Fenoy E., Leon D., Penalver P., Toja J. and Casas J.J., 2013. Diversity in Mediterranean farm ponds: trade-offs and synergies between irrigation modernisation and biodiversity conservation. Freshw. Biol., 58, 63-78.

Gama M., Guilhermino L. and Canhoto C., 2014. Comparison of three shredders response to acute stress induced by eucalyptus leaf leachates and copper: single and combined exposure at two distinct temperatures. Ann. Limnol. - Int. J. Lim., 50, 97-107.

Gerber A. and Gabriel M.J.M., 2002. Aquatic Invertebrates of South African Rivers: Field Guide, 1st edn, Resource Quality Services, Department of Water Affairs and Forestry, South Africa, Pretoria, $150 \mathrm{p}$.

Hastie T.J. and Tibshirani R.J., 1990. Generalized Additive Models, Chapman \& Hall, London, 352 p.

Heck K.L., Vanbelle G. and Simberloff D., 1975. Explicit calculation of rarefaction diversity measurement and determination of sufficient sample size. Ecology, 56, 1459-1461.
Heino J., Parviainen J., Paavola R., Jehle M., Louhi P. and Muotka T., 2005. Characterizing macroinvertebrate assemblage structure in relation to stream size and tributary position. Hydrobiologia, 539, 121-130.

Hering D., Moog O., Sandin L. and Verdonschot P.F.M., 2004. Overview and application of the AQEM assessment system. Hydrobiologia, 516, 1-20.

Hering D., Johnson R.K., Kramm S., Schmutz S., Szoszkiewwicz K. and Verdonschot P.F.M., 2006. Assessment of European streams with diatoms, macrophytes, macroinvertebrates and fish: a comparative metric-based analysis of organism response to stress. Freshw. Biol., 51, $1757-1785$.

Herlihy A.T., Gerth W.J., Li J. and Banks J.L., 2005. Macroinvertebrate community response to natural and forest harvest gradients in western Oregon headwater streams. Freshw. Biol., 50, 905-919.

Hoang D.H. and Bae Y.J., 2006. Aquatic insect diversity in a tropical Vietnamese stream in comparison with that in a temperate Korean stream. Limnology, 7, 45-55.

Hyslop E.J. and Hunte-Brown M., 2012. Longitudinal variation in the composition of the benthic macroinvertebrate fauna of a typical North coast Jamaican river. Revista de Biologia Tropical(Int. J. Trop. Biol.), 60(1), 291-303.

Imoobe T.O.T. and Ohiozebau E., 2009. Pollution status of a tropical forest river using aquatic insects as indicators. Afr. J. Ecol., 48, 232-238.

Kasangaki A., Babaasa D., Efitre J., Mcneilage A. and Bitariho R., 2006. Links between anthropogenic perturbations and benthic macroinvertebrate assemblages in Afromontane forest streams in Uganda. Hydrobiologia, 563, 231-245.

Kasangaki A., Chapman L.J. and Balirwa J., 2008. Land use and the ecology of benthic macroinvertebrate assemblages of high-altitude rainforest streams in Uganda. Freshw. Biol., 53, 681-697.

Kaufmann P.R. and Faustini J.M., 2012. Simple measures of channel habitat complexity predict transient hydraulic storage in streams. Hydrobiologia, 685, 69-95.

Kouamé M.K., Diétoa M.Y., Edia O.E., Da Costa S.K., Ouattara A. and Gourène G., 2011. Macroinvertebrate communities associated with macrophyte habitats in a tropical man-made lake (Lake Taabo, Côte d'Ivoire). Knowl. Manag. Aquat. Ecosyst., 400, 03.

Lévêque C., Hougard J.M., Resh V.H., Statzner B. and Yaméogo L., 2003. Freshwater ecology and biodiversity in the tropics: what did we learn from 30 years of onchocerciasis control and the associated biomonitoring of West African rivers? Hydrobiologia, 500, 23-49.

Maue T. and Springer M., 2008. Effect of methodology and sampling time on the taxa richness of aquatic macroinvertebrates and subsequent changes in the water quality index from three tropical rivers, Costa Rica. Rev. Biol. Trop., 56 (Suppl. 4), 257-271.

Mellanby H., 1963. Animal Life in Fresh Water: A Guide to Fresh-water Invertebrates, 6th edn, Chapman and Hall, London, 308 p.

Minaya V., McClaina M.E., Moog O., Omengo F. and Singer G.A., 2013. Scale-dependent effects of rural activities on benthic macroinvertebrates and physico-chemical characteristics in headwater streams of the Mara River, Kenya. Ecol. Indic., 32, 116-122. 
Miserendino M.L., Brand C. and Di Prinzio C.Y., 2008. Assessing urban impacts on water quality, benthic communities and fish in streams of the Andes Mountains, Patagonia (Argentina). Water Air Soil Poll., 194, 91-110.

Ndaruga A.M., Ndiritu G.G., Gichuki N.N. and Wamicha W.N., 2004. Impact of water quality on macroinvertebrate assemblages along a tropical stream in Kenya. Afr. J. Ecol., 42, 208-216.

Oksanen J., Blanchet F.G., Kindt R., Legendre P., Minchin P.R., O’Hara R.B., Simpson G.L., Solymos P., Stevens M.H.H. and Wagner H., 2013. vegan: Community Ecology Package. R package version 2.0-8.

Olomukoro J.O. and Ezemonye L.I.N., 2007. Assessment of the macro-invertebrate fauna of rivers in southern Nigeria. Afr. Zool., 42, 1-11.

R Core Team. 2013. R: A Language and Environment for Statistical Computing. R Foundation for Statistical Computing, Vienna, Austria, Available online at: http:// www.R-project.org/

Rawi C.S.M., Al-Shami S.A., Madrus M.R. and Ahmad A.H., 2013. Local effects of forest fragmentation on diversity of aquatic insects in tropical forest streams: implications for biological conservation. Aquat. Ecol., 47, 75-85.
Stals R. and De Moor I.J., 2007. Freshwater Invertebrates of Southern Africa, Volume 10: Coleoptera, WRC Report, South Africa, Pretoria, 263 p.

Suriyawong P., Thapanya D., Bergey E.A. and Chantaramongkol P., 2015. Seasonal Variation of Aquatic Insect Communities and Environmental Characteristics in a Regulated Mountain Stream. The 3rd Environment Asia International Conference on "Towards International Collaboration for an Environmentally Sustainable World". June 17-19, 2015, Montien Riverside Hotel, Bangkok, Thailand. Thai Society of Higher Education Institutes on Environment: 242-250.

Thorne R.S.J., Williams W.P. and Gordon C., 2000. The macroinvertebrates of a polluted stream in Ghana. J. Freshw. Ecol., 15, 209-217.

Tomanova S., Goitia E. and Helesic J., 2006. Trophic levels and functional feeding groups of macroinvertebrates in neotropical streams. Hydrobiologia, 556, 251-264.

Ward J.V., 1992. Aquatic Insect Ecology. 1- Biology and Habitat, John Wiley \& Sons, Inc, New York/Chichester/ Brisbane/Toronto/Singapore, $438 \mathrm{p}$.

Wood S., 2014. mgcv: Mixed GAM Computation Vehicle with GCV/AIC/REML smoothness estimation. R package version $1.7-29$. 


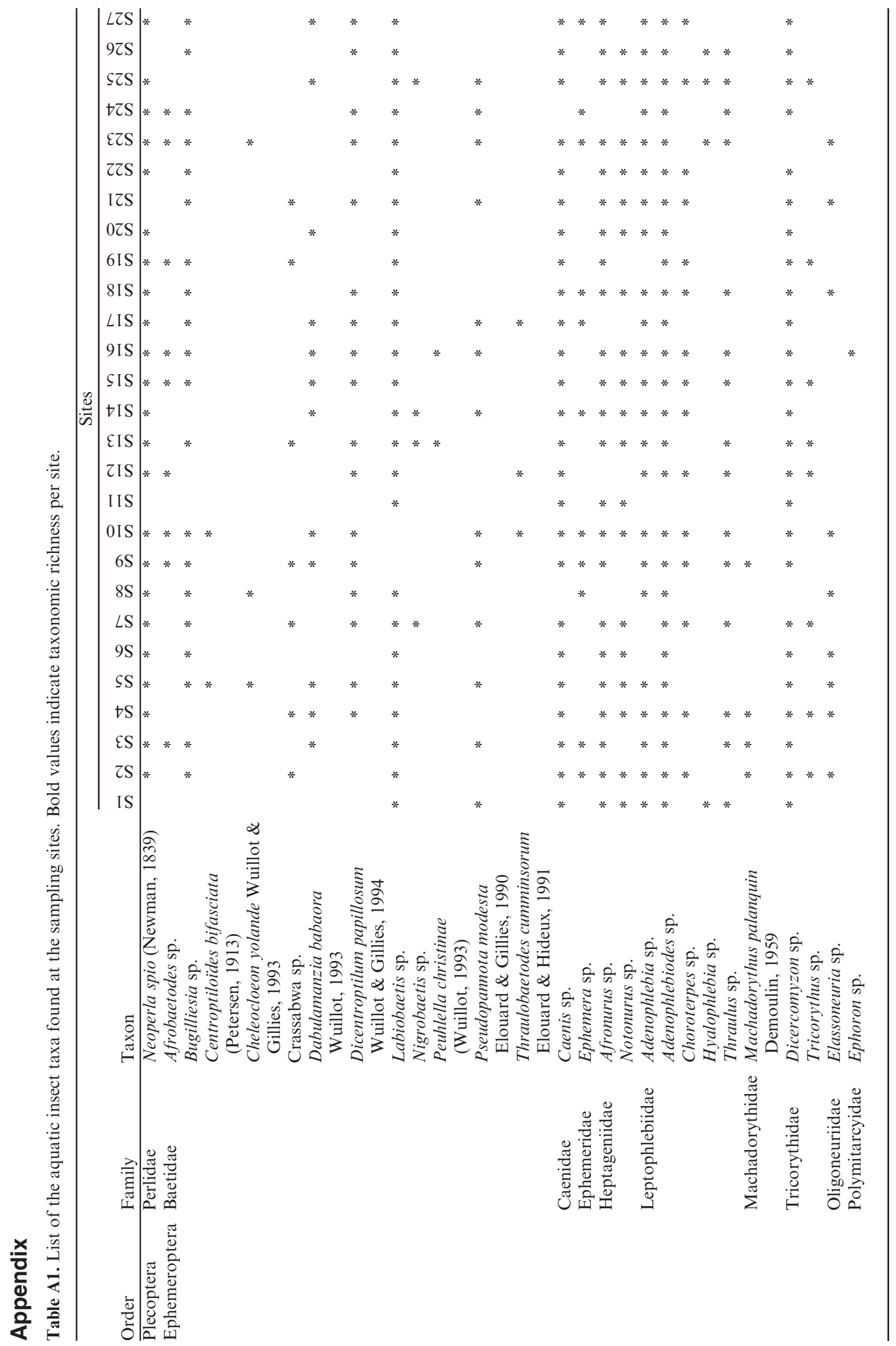




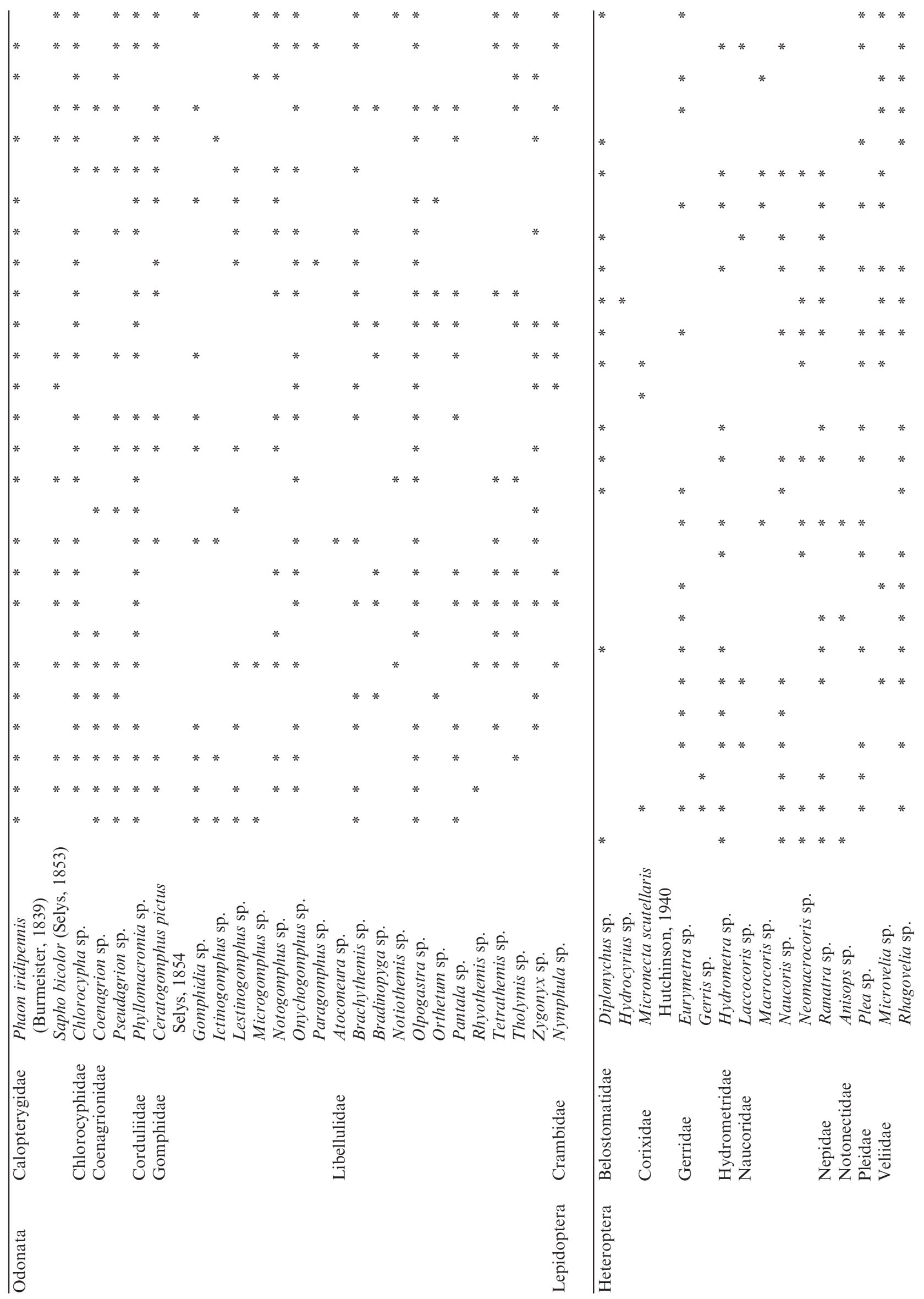




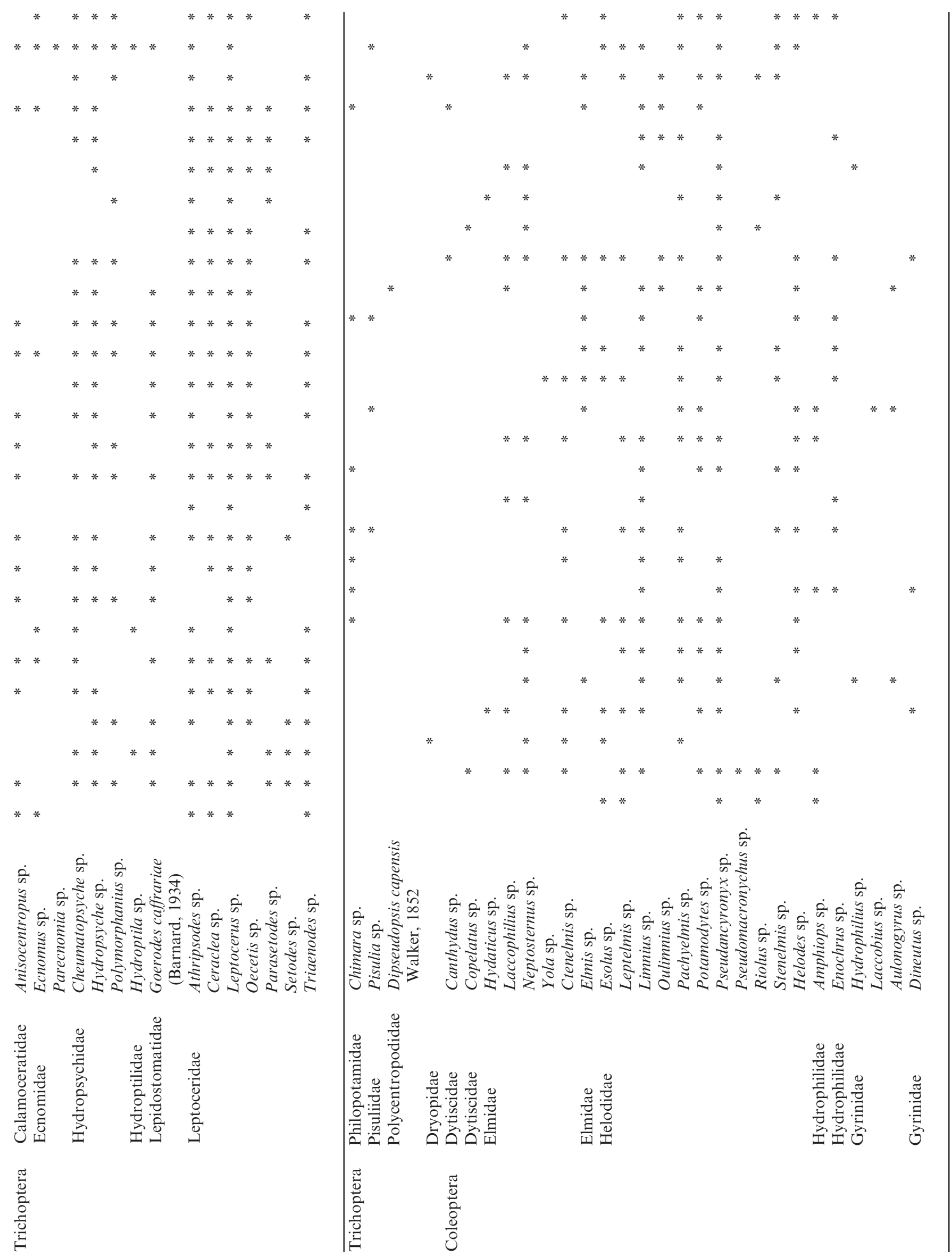




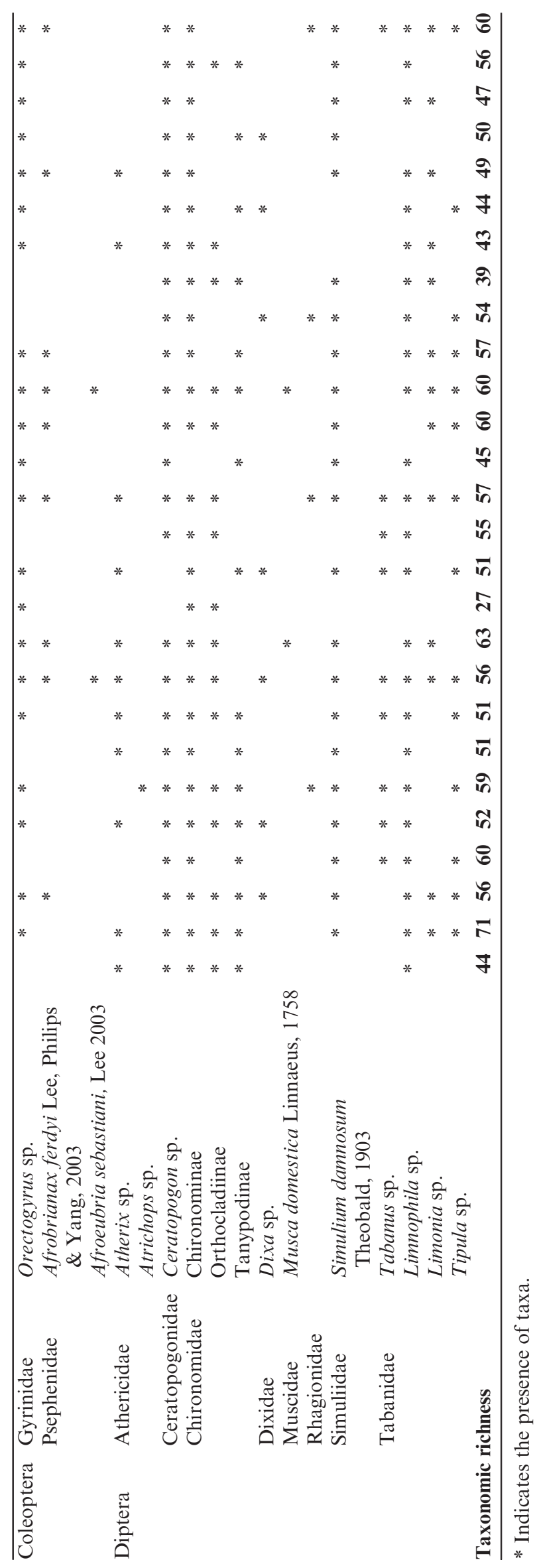

